DOI: https://doi.org/10.24113/ijellh.v8i1.10410

\title{
Journey of Savitri From Birth to Young-Age: Tale of a Legend in Sri Aurobindo's Epic "Savitri”"
}

Dr. Sumit Kumari Dahiya

Assistant Professor of English

Sh. L.N. Hindu (PG) College

Rohtak, Haryana,India

Ms. Harshita Chikkara

Assistant Professor of English

Sh. L.N. Hindu (PG) College

Rohtak, Haryana, India

harshita.hc18@gmail.com

\section{Abstract}

Yoga leads to right knowledge and right knowledge makes right action possible. The struggle and the victory are the hard core of poetry "Savitri". The legend Savitri's birth and childhood are far from conventional. Her girldhood is a wonder. She is a king's daughter. But she masters sculpture and painting, music and architecture, dance and poetry and many other arts and crafts. She is divine and outspaces her friends. She is a divine beauty and nobody dares to claim her. She is free to choose her husband. Savitri leaves her parent's home, her palace. She visits many places and many woods. She is attracted towards Satyawan. He tells that he is a son of king, but a king no more. Savitri becomes sure in her decision to marry Satyawan but 
DOI: https://doi.org/10.24113/ijellh.v8i1.10410

before this, she wants to return to her parents to tell them about her choice. Inspite of being intimations of future, she is committed to her chosen path.

Keywords: Savitri Yoga, Legend, Divine, Satyawan, Committed, Predestination

The gist of Sri Aurobindo's philosophy is that it establishes the oneness of The

Absolute or Brahman with full agreement of real world. Sri Aurobindo was a great philosopher but his philosophy is not fine product of his intellect only, it has grown out of his life experience. "Savitri" by Sri Aurobindo is the answer to our existential problem. Yoga leads to right knowledge and right knowledge makes right action possible. She is redeemer of her husband and she is the redeemer of the world. Aswapathy's (Savitri's father) yoga articulates the earth's cry for perfection, and in answer, the power behind the cosmos promises the advent of Savitri. The struggle and the victory are the hard core of poetry "Savitri'. The cycle of seasons is completed by revolving earth's participation. As the days and months pass as three thoughtful seasons scan their pregnant hours, there is the expectancy of a flame, a mighty birth to come.

Spring represents "arrival of joy" always. Aswapathy's unique joy increased when his prayer was answered and "a mediating ray" touches the human vessel and lights a new lamp. Savitiri is conceived, Savitri is born. She is on earth with a purpose:

"Even in her childish movements could be felt

The nearness of light still kept from earth...

As needing nothing but its own rapt flight

Her nature dwelt in a strong separate air'

(ibid, p. 400)

Savitri is ruled by an occult godhead. Her girldhood is a wonder as she is apparently at home in the world of Nature and Man. As "Krishna Lila" reveals the boy who was also God, the 
DOI: https://doi.org/10.24113/ijellh.v8i1.10410

innocence that was also wisdom. Similarly, in the life of the child and girl Savitri, a slight line separates the human from the divine:

A new epiphany appeared in her,

A mind of light, a life of rhythmic force,

A body instinct with hidden divinity

Prepared an image of the coming god... (ibid, p. 406)

The legend Savitri's birth and childhood are far from conventional. The cosmic and terrestrial planes meet in an intimate embrace, and out of the flux and the tension, the passion and the creative will, child Savitri is born. The occult powers behind the phenomena of Nature, Savitri draws herself other powers too:

An invisible sunlight ran within her veins

And flooded her brain with heavenly brilliancies

That woke a wider sight than earth could know.

(ibid, p. 405)

The child grows into the girl, and the girl becomes a young woman. Savitri is a king's daughter. Her father Aswapathy rules over the land of Madra, as rich and colorful in its landscape. She is the dream made real, “an image made of heaven's transparent light, a perfect whole and a golden bridge spanning earth and heaven. Savitri grows as a child in a properly adjusted society. Beauty in art and nature, the harmony of a rich culture's tones, the climb of the mind to eagle-heights, the leaps of thought, all play their part in Savitri's mental and spiritual evolution. Savitri master sculpture and painting, music and architecture, dance and poetry, the many arts and crafts. Savitri thirsts for something vaster still, for the knowledge that exceeds the knowledge, for the art and wisdom of the Gods:

It asked for objects around which to grow 
DOI: https://doi.org/10.24113/ijellh.v8i1.10410

And natures strong to bear without recoil

The Splendour of her native royalty.... (ibid, p. 411)

She sees others as her soul's reflections, complements and counterparts. But her friends and companions miss the main aim of her life:

Only a few responded to her call

Still fewer felt the screened divinity. (ibid, p. 412)

Among her friends, she is divine and outpaces them. The news of her rare beauty and power runs in the society. But none dares to claim her. King Aswapathy becomes sed finding that there are no suitors. He asks her to look for herself and choose a husband, worthy of her. She shall now go out into the world and choose the Lord of her life;

Who shall give voice to what in thee is mute...

Ascend from Nature to divinity's heights;

Face the high gods, crowned with felicity,

Then meet a greater God, thy self beyond time.

(ibid, pp. 425-6)

Savitri leaves her parents' home, her palace. She is a part of all she meets, the very stars and wind. In woods, Savitri visits strong king-sages and their young grave disciples They are masters of knowledge and are the healers of the hard and wounded World Savitri sees a man, he looks "a king of life outlined in delicate air". Destiny had sent him. He has a muscular strength and a soul mastering all knowledge. Their eyes meet and the great alchemy works:

Then trembling with the mystic shock her heart

Moved in her breast and cried out like a bird

Who hears his mate upon a neighbouring bough. (ibid, p. 448)

Savitri is like an arrested person and Satyawan, now, is alerted into attention. As dazed Satyawan dares Savitri's eyes:

He met in her regard his future's gaze, 
DOI: https://doi.org/10.24113/ijellh.v8i1.10410

A promise and a presence and a fire,

Saw an embodiment of aeonic dreams.... (ibid., p. 449)

They are no strangers but 'soul-mates' since the beginning of things. Savitri, tells-her name "I am Savitri, Princess of Madra: - and asks in turn for his. He tells, he is Satyawan, the Shalwa King Dyumathsena's son but a king no more, for he has lost eyesight and kingdom both. Savitri is like a healer to Satyawan.

In India from times immemorial, it is the girl who advances, bashfully yet bravely, with garland in hand so and so does Savitri here:

A candid garland set with simple forms

she brought, flower-symbol of her offered life..

she bowed and touched his feet with worshipping hand. (ibid, pp. 463-4)

Satyawan humbly blends to receive her and embraces her. They moves to their future home but Savitri needs must return of Madra and tell Aswapathy the choice she has made. Aswapthy asks her to choose again but Savitri says that she can but choose once. Here, Sri Aurobindo gives the key place to this act of will on Savitri's part. It's a positive act of commitment to a chosen course, come what may. She will not be deflected from her chosen path by these advancing intimations of predestination. Savitri decides to stand strictly on her decision. 
DOI: https://doi.org/10.24113/ijellh.v8i1.10410

\section{References}

Savitri, Sri Aurobindo International University Centre Collection, published in 1954.

(The page references are throughout standard edition of this book).

Deshmukh, P.S. The Origin and Development of Religion in Vedic Literature (Oxford University Press, 1933)

Roy, Partap Chandra, The Mahabharata, Vol. II, Vana Parva, Englsh Translation (Datta Bose \& Co., Calcutta)

Smith, G.C. Moore (Ed.) Essays \& Studies, Vol. VIII (The Clarenden Pres, Oxford 1922)

$\underline{\text { https://www.questia.com>journel }}$

https://www.motherandsriaurobindo.in

https://en.m.wikipedia.org>wiki 